\title{
Prognostic Significance of Matrix Metalloproteinase 2 and Tissue Inhibitor of Metalloproteinase 2 Expression in Prostate Cancer
}

\author{
Jeffrey S. Ross, M.D., Prabhjot Kaur, M.D., Christine E. Sheehan, B.S, Hugh A.G . Fisher, M.D., \\ Ronald A. Kaufman, Jr, M.D., Bhaskar V. S. Kallakury, M.D. \\ Departments of Pathology and Laboratory Medicine (JSR, PK, CES, BVSK) and Surgery (Urology; HAGF, \\ RAK Jr), Albany Medical College, Albany, New York
}

\begin{abstract}
Matrix metalloproteinases (MMPs) are proteolytic enzymes capable of degrading the structural support network for normal and malignant cells, promoting neoplastic cell invasion and metastasis. Tissue inhibitors of metalloproteinases (TIMPs) maintain connective tissue integrity by modulating MMP activity. Formalin-fixed paraffin-embedded tissue sections from 138 prostatic adenocarcinomas (PACs) were immunostained by a combined automated/manual method using monoclonal antibodies against MMP2 and TIMP2. Immunoreactivity was semiquantitatively scored based on stain intensity and distribution, and results were correlated with Gleason grade, pathologic stage, ploidy status, and disease recurrence. One hundred five of 138 (76\%) and 113/138 (82\%) PACs expressed MMP2 and TIMP2, respectively. Co-expression was observed in 94/138 $(68 \%)$ of PACs $(P=.01)$, correlated with advanced tumor stage $(P=.05)$, and tended to be associated with disease recurrent cases $(P=.07)$. TIMP2 expression individually correlated with advanced tumor stage $(P=.04)$ and reached near significance with disease recurrence $(P=.06)$. MMP2 expression was also more frequent in recurrent PACs, although this value did not reach statistical significance $(P=.07)$. However, on multivariate analysis, only pathologic stage $(P=.009)$ and ploidy status $(P=.03)$ independently predicted disease recurrence. In conclusion, MMP2 and TIMP2 are co-expressed in a majority of PACs and correlate with prognostic variables. Interestingly, contrary to
\end{abstract}

\footnotetext{
Copyright (C) 2003 by The United States and Canadian Academy of Pathology, Inc.

VOL. 16, NO. 3, P. 198, 2003 Printed in the U.S.A

Date of acceptance: January 6, 2002.

Presented in part at the 90th annual meeting of the United States and Canadian Academy of Pathology, March 2001, Atlanta, Georgia.

Address reprint requests to: Jeffrey S. Ross, M.D., Department of Pathology and Laboratory Medicine, Albany Medical College, Mail Code 81, 47 New Scotland Avenue, Albany, NY 12208; fax: (518) 262-3663; e-mail: rossj@mail.amc.edu.

DOI: 10.1097/01.MP.0000056984.62360.6C
}

the previously documented anti-tumor effects of TIMPs, TIMP2 expression appears to have a tumorpromoting role in PACs and warrants further investigation.

KEY WORDS: Immunohistochemistry, MMP, Prognosis, Prostate cancer, TIMP.

Mod Pathol 2003;16(3):198-205

Matrix metalloproteinases (MMPs), a family of zinc-dependent endopeptidases, degrade the basement membrane and extracellular matrix, facilitating cell migration, tumor invasion, and metastasis (1-5). There are at least 20 human MMPs, divided into the collagenases, gelatinases, stromelysins, and membrane-type MMPs (MT-MMPs; 1-5). Tissue inhibitors of metalloproteinases (TIMPs) are the major endogenous regulators of MMPs and consist of four homologous members (TIMP1-4; 6-8). TIMPs are multifunctional proteins that inhibit cell invasion in vitro and tumorigenesis and metastasis in vivo (6). Although each TIMP appears capable of inhibiting several MMPs, these proteins exhibit preferential inhibitory capacity; for example, TIMPs1 and 2 selectively inhibit MMP9 and 2, respectively (9).

Increased expression of MMPs has been associated with poor prognosis and shortened patient survival in a variety of malignancies including carcinomas of the esophagus (10), stomach (11), colon (12), breast (13), pancreas (14), lung (15), kidney (16), and ovary (17). TIMP expression has been associated with both tumor suppressor or antimetastatic effects and tumor-promoting effects in selected cancers (18-20). MMP and TIMP expression in prostate cancer has been recently reviewed (21). Both MMPs and TIMPs have been characterized in prostate cancer cell lines (22-25) and clinical samples from prostate cancer patients (26-33), with conflicting results. Similarly, serum levels of circulating MMPs and TIMPs have shown variable 
capability of predicting disease progression (3437 ). The aim of the current study was to evaluate the immunohistochemical expression of MMP2 and TIMP2 in prostate cancer and determine whether the expression of these markers correlates with prognostic variables, including patient survival.

\section{MATERIALS AND METHODS}

\section{Patients and Specimens}

One hundred thirty-eight randomly selected prostatic adenocarcinomas (PACs) treated by radical retropubic prostatectomy obtained from the files of the Albany Medical Center Hospital between 1987 and 1997 were included in this study. All hematoxylin and eosin-stained slides from each case were reviewed, and tumors were graded according to the Gleason system (38) and staged according to TNM criteria (39). Multiple blocks were identified based on the presence of adequate tumor and the representative nature of the overall grade. For statistical evaluations, tumors with Gleason scores of 6 or lower were considered as low grade, and tumors with Gleason scores of 7 or higher were considered as high grade. Statistical analysis was also performed using a three-tier scheme isolating tumors with Gleason score of 7. Serum PSA levels as measured by the Hybritech Tandem method (Hybritech) were obtained from review of the patients' medical records. Postoperative PSA of $>0.4 \mathrm{ng} / \mathrm{mL}$ on two consecutive occasions after prostatectomy was considered as biochemical evidence of disease recurrence.

\section{Immunohistochemistry}

To analyze for the expression of MMP2 and of TIMP2 proteins, contiguous $4-\mu \mathrm{m}$ sections were cut from a single block of formalin-fixed, paraffinembedded tissue randomly chosen from those initially identified; sections were placed on charged slides. After deparaffinization, primary antibody incubation was performed by an automated system (Ventana Medical Systems, Tucson, AZ) for MMP2 and manually for TIMP2. Pertinent details regarding antibodies and staining procedure are summarized in Table 1 . The remainder of the staining procedure included incubation with a biotinylated anti-mouse secondary antibody, diaminobenzidine substrate, and hematoxylin counterstain and was performed on the Ventana ES automated immunohistochemistry system. Negative-control slides were incubated with isotype-matched immunoglobulin in parallel with each batch of staining to confirm the specificity of the antibodies.

\section{Staining Interpretation}

Staining results were interpreted without prior knowledge of clinical and pathologic parameters by two observers using a consensus method. For all markers, both the intensity of staining and approximate percentage of positive tumor cells were considered in the semiquantitative assessment, as previously published $(40,41)$. Briefly, the distribution of positive staining in the tumors was graded as focal ( $\leq 10 \%)$, regional (11-50\%), and diffuse $(>50 \%)$. The staining intensity was subjectively scored as weak, moderate, or intense. Staining patterns of moderate diffuse, moderate regional, intense regional, and intense diffuse were considered as increased expression of each protein.

\section{Quantitative DNA Analysis}

Quantitative analysis of DNA content was determined for each case using $5-\mu \mathrm{m}$ tissue sections stained by the Feulgen reaction and evaluated by the CAS 200 image analyzer (Tripath Corp., Burlington, NC), as previously described $(42,43)$.

\section{Statistical Analysis}

Statistical comparisons were performed using Stata software (Stata Corp, College Station, TX). Correlation between protein expression and pathologic variables was performed using the $\chi^{2}$ univariate analysis. Survival curves for all univariate analyses were assessed using the Kaplan-Meier method. Overall survival was defined as the interval between surgery and postsurgical biochemical disease recurrence. Multivariate analyses of clinicopathologic parameters, including survival, were performed using the Cox proportional hazards model. The level of significance was set at .05 .

\section{RESULTS}

Of the 138 PACs, there were 75 (54\%) low-grade and 63 (46\%) high-grade tumors. At prostatectomy, there were $78(57 \%)$ organ-confined tumors (Stages I and II) and 60 (43\%) advanced-stage (Stages III

TABLE 1. Antibodies and Immunohistochemical Procedure

\begin{tabular}{cllccc}
\hline Antibody & Manufacturer & Clone & $\begin{array}{c}\text { Citrate Antigen } \\
\text { Retrieval (min) }\end{array}$ & $\begin{array}{c}\text { Antibody } \\
\text { Dilution }\end{array}$ & $\begin{array}{c}\text { Primary Antibody } \\
\text { Incubation }\end{array}$ \\
\hline MMP2 & Novocastra & 4D3 & 60 & $1: 10$ & 32 min at $41^{\circ} \mathrm{C}$ \\
TIMP2 & Neomarkers & 2TMP04 & 60 & $1: 10$ & Overnight at $4^{\circ} \mathrm{C}$ \\
\hline
\end{tabular}


and IV) cancers. Of the 77 cases tested for total DNA content, 52 (68\%) were diploid, and 25 (32\%) were nondiploid. A total of 131/138 (95\%) had sequential serum PSA follow-up information available. Of these 131 patients, $50(38 \%)$ had biochemical postsurgical disease recurrence.

\section{Immunohistochemistry and Statistical Analysis}

Immunostaining pattern for both proteins was cytoplasmic, with tumor cells showing moderate to intense positivity, as opposed to relatively weaker expression in the benign elements, which served as internal control in each case. One hundred five of 138 (76\%) PACs expressed MMP2, and 113/138 (82\%) expressed TIMP2. There was an overall significant coexpression of MMP2 and TIMP2 in 94/ $138(68 \%)$ PACs $(P=.01$; Fig. 1$)$. The co-expression of MMP2 and TIMP2 correlated with advanced tumor stage $(P=.05)$ and reached near-significance as a univariate predictor of disease recurrence $(P=$ .07). TIMP2 expression individually correlated with advanced tumor stage $(P=.04$; Fig. 2$)$ and reached near significance with disease recurrence $(P=.06$; Fig. 3). MMP2 expression was also more frequent in the PACs that recurred, although this value did not reach statistical significance $(P=.07)$. On univariate analysis, neither MMP2 nor TIMP2 expression correlated with tumor grade (using either the twoor three-tier scheme) or DNA ploidy.

On multivariate analysis, only tumor stage $(P=$ .009) and DNA ploidy status $(P=.03)$ independently predicted disease recurrence.

\section{DISCUSSION}

MMP expression has been reported to be low or undetectable in most benign elements but is substantially increased in a majority of human malignancies (10-21). Analysis of both primary and metastatic tumors has shown increased relative MMP expression at the metastatic site, supporting a role in tumor migration and spread (44). Additionally, increased MMP levels have been reported in the plasma and urine of patients with a variety of advanced malignancies (45). Cancer outcome studies have also shown that increased expression of MMPs is associated with shortened patient survival $(10,12$, 46). Aberrant expression of MMPs in prostate cancer was first described using in situ hybridization in 1991 (31). MMP7 expression has been linked to prostate cancer pathologic stage and incidence of metastasis (33). Using both Northern analysis and in situ hybridization, Still and co-workers (27) linked increased MMP2 and TIMP2 to high tumor grade and advanced tumor stage of the disease. Increased MMP2 expression has also been associated with high tumor Gleason score (28). Finally, increased MMP expression also has been implicated in the development of prostate cancer, as evidenced by increased levels found in carcinomas versus benign prostatic hypertrophy and prostatic intraepithelial neoplasia $(47,48)$.

Serum measurements of MMPs in prostate cancer have yielded conflicting correlations with disease outcome. Several studies have found a correlation between circulating MMPs (MMP1,2,3) and circulating TIMPs (TIMP1,3) and advanced or progressive disease $(34,36)$; others have failed to confirm this association (35).

In the present study, increased immunohistochemical co-expression of MMP2 and TIMP2 was associated with advanced tumor stage and reached near-significance as a predictor of disease recurrence. TIMP2 expression correlated with tumor grade and predicted disease recurrence on univariate analysis but was not an independent predictor when tumor stage and DNA ploidy status were included in the multivariate analysis model.

At the time of their discovery, TIMPs were considered to be tumor suppressor proteins. Recombinant TIMP2 was shown to inhibit invasion of HT 1080 fibrosarcoma cells in vitro (49). Increased TIMP expression has been associated with decreased tumor growth, invasiveness, and metastasis in a variety of prostate cancer and non-prostate cancer cell lines $(22-25,49-52)$. However, the results of the current study, demonstrating a poor prognostic significance in prostate cancer for increased TIMP2 expression, are contrary to the original tumor suppressor role hypothesized for TIMPs and more in line with recent evidence documenting a multifunctional complex role for TIMPs. Nemith et al. (53) described the growth-promoting abilities of TIMP2 in several human cell types, including fibroblasts, keratocytes, lymphocytes, and stem cells. Increased TIMP1 and TIMP2 mRNA levels have been correlated with tumor stage, lymph node metastasis, and shortened survival in patients with carcinomas of colon (18), breast (19), and bladder (54). Our findings of the poor prognostic role of increased TIMP2 expression in prostate cancer also concur with the data of Kugler et al. (16), which demonstrated a correlation of increased TIMP2 levels with aggressive phenotype in renal cell carcinoma.

Although the paradoxical positive effect of TIMP in tumor progression is not completely understood, the tumor-promoting activity may be due either to proteolytic degradation of ECM or direct influence on cell survival and growth. TIMP2 is reported to regulate matrix degradation, acting through a membrane type MMP (MT1-MMP; 55, 56). MT1MMP is a key enzyme in tumor angiogenesis and metastasis, hydrolyzes a variety of ECM components, and is a physiologic activator of pro-MMP2 


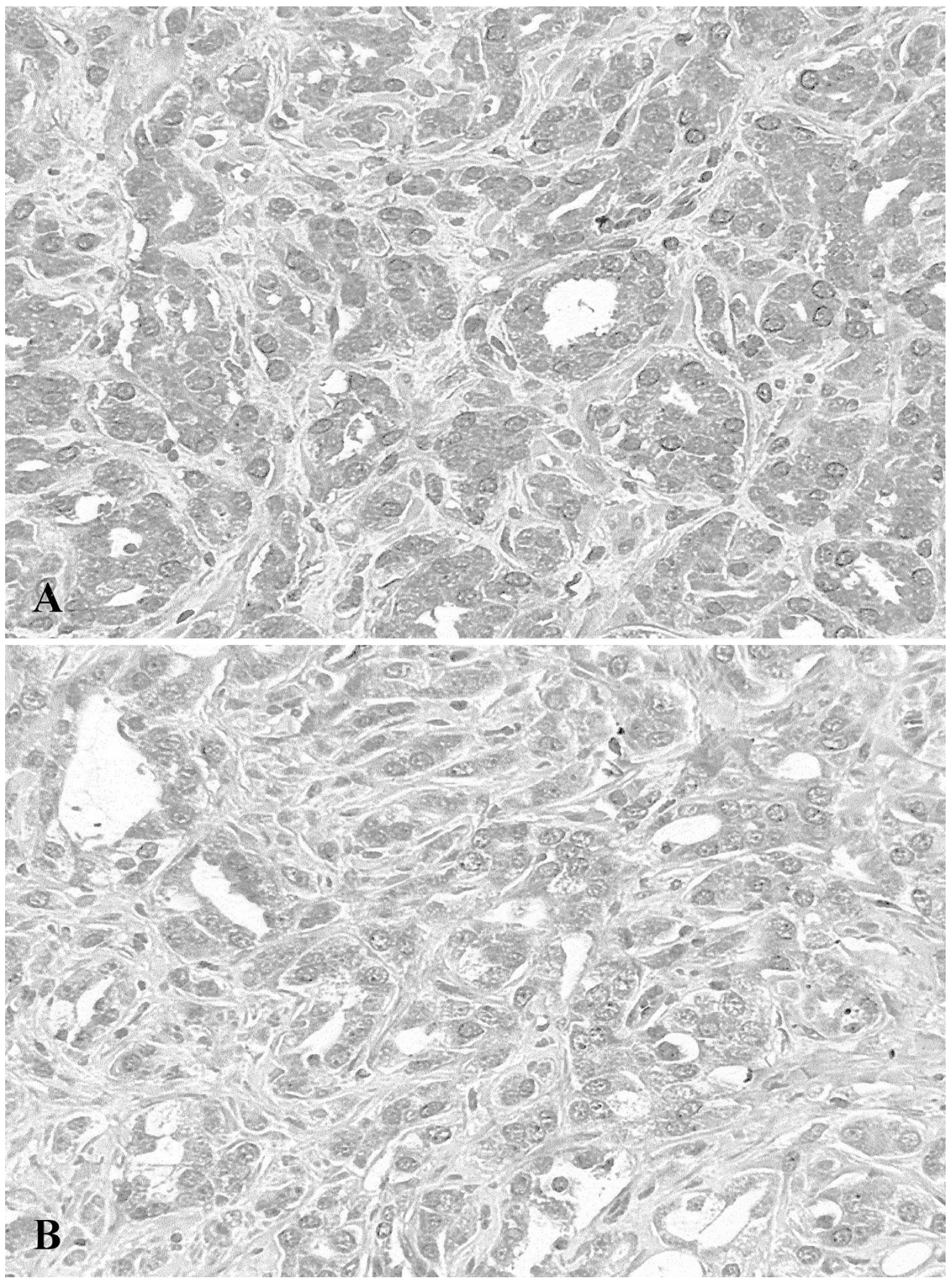

FIGURE 1. An example of the same case of prostatic adenocarcinoma showing co-expression of MMP2 (A) and TIMP2 (B) proteins. (3,3'-diaminobenzidine; hematoxylin, 200×).

(57). TIMP2 forms a complex with MT1-MMP and pro-MMP2 on the cell surface, promoting hydrolysis of pro-MMP2 to its active form (MMP2) and resulting in degradation of ECM. Also, formation of this complex decreases the autocatalysis of MT1MMP, resulting in increased levels of its active form. It also has been reported that some TIMPs can directly affect cell growth and survival, independent of their actions on MMPs. Stimulation of cell growth by TIMPs is thought to be mediated by c-AMP-dependent activation of protein kinase A (58) and increased tyrosine phosphorylation (59). 


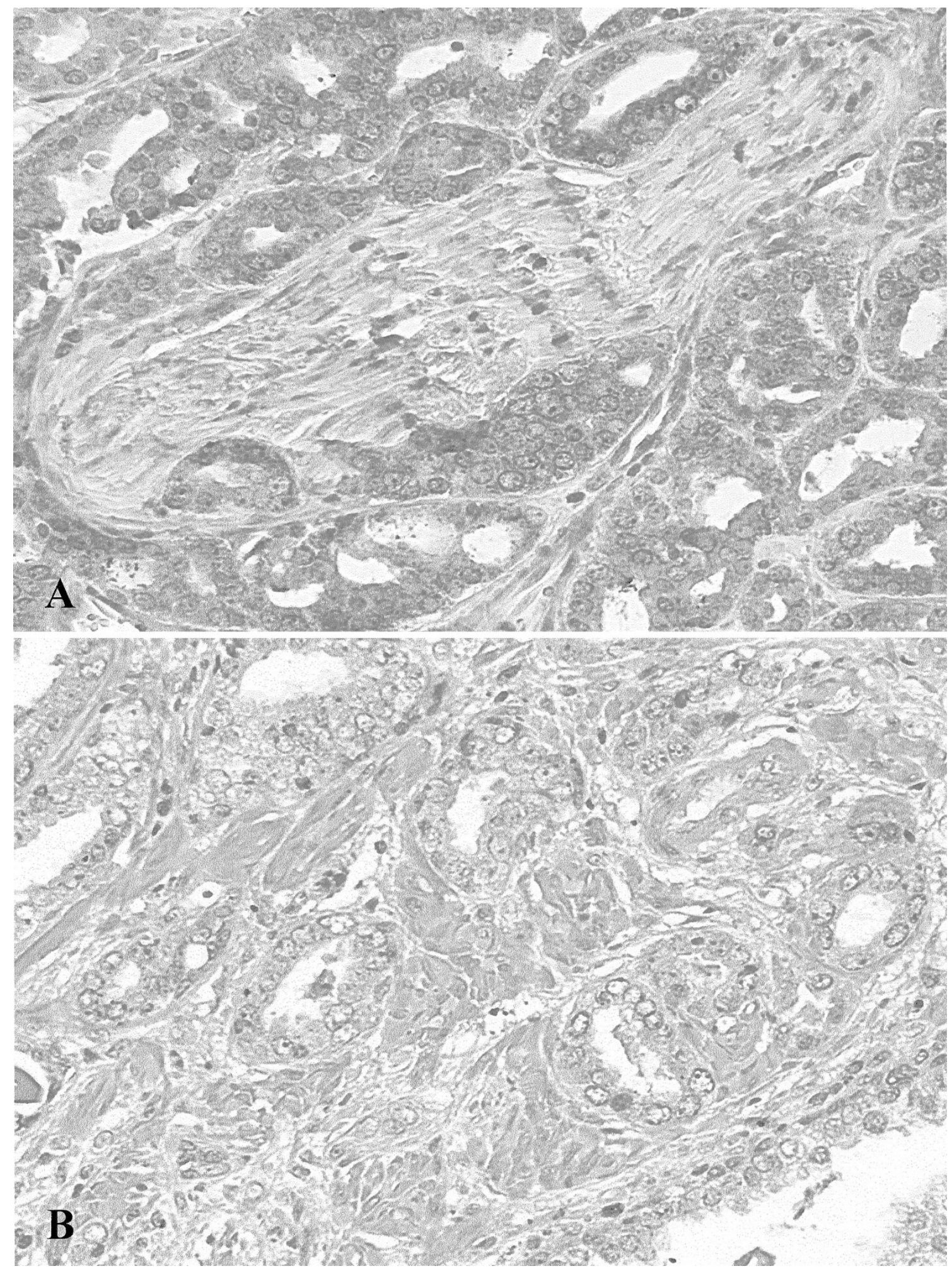

FIGURE 2. A Stage 3 prostatic adenocarcinoma with perineural invasion expressing TIMP2 protein (A) in comparison to its absence in tumor glands of a Stage 2 cancer (B). (3,3'-diaminobenzidine; hematoxylin, 200×).

Cell survival is prolonged by the TIMP1-mediated upregulation of anti-apoptotic protein bcl-XL and by decreased NF Kappa B activity (60). Several additional factors that may play key roles in the TIMP promotion of cancer progression include the following: local TIMP concentration, cellular distribu- tion, association with pro-MMPs, and presence of TIMP receptors $(61,62)$.

In view of their important role in tumor invasion and metastasis, inhibitors of MMP activity have been investigated as a method of preventing or decreasing tumor spread. Clinical trials involving 
Kaplan-Meier survival estimates, by TIMP2 expression

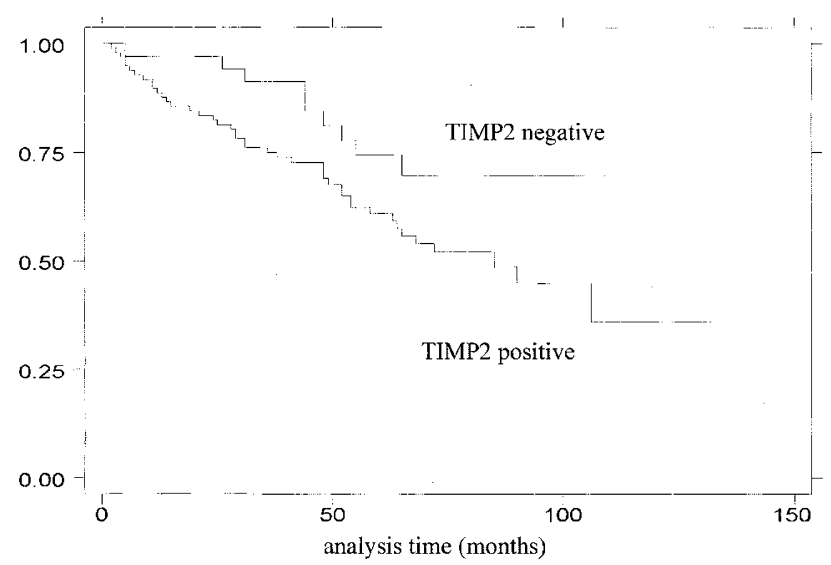

FIGURE 3. Kaplan-Meier estimates showing correlation between TIMP2 protein expression and postsurgical disease recurrence $(P=$ $.05)$.

batimastat (British Biotech), a potent, broad-based inhibitor of MMPs 1, 2, 3, and 9 (63), and marimastat (British Biotech), a second-generation, water-soluble synthetic MMP inhibitor, have been associated with clinical responses in pancreatic, pulmonary, ovarian, and mammary carcinomas (63). In preclinical studies of prostate cancer, anti-tumor effects of MMP inhibitors (doxycycline and chemically modified tetracyclines), both in vitro and in vivo, have been reported (21).

In conclusion, co-expression of MMP2 and TIMP2 proteins bears prognostic significance in patients with prostate cancer and supports a potential therapeutic role for synthetic MMP inhibitors. The paradoxical poor prognostic significance of TIMP2 expression warrants further investigation into the complex MMP-TIMP interactions and into the role of TIMPs in tumor evolution and spread.

\section{REFERENCES}

1. Nagase H, Woessner JF. Matrix metalloproteinases. J Biol Chem 1999;274:21491-4.

2. Curran S, Murray GI. Matrix metalloproteinases: molecular aspects of their roles in tumour invasion and metastasis. Eur J Cancer 2000;36:1621-30.

3. Johansson N, Ahonen M, Kahari VM. Matrix metalloproteinases in tumor invasion. Cell Mol Life Sci 2000;57:5-15.

4. Curran S, Murray GI. Matrix metalloproteinases in tumour invasion and metastasis. J Pathol 1999;189:300-8.

5. Kahari VM, Saarialho-Kere U. Matrix metalloproteinases and their inhibitors in tumour growth and invasion. Ann Med 1999;31:34-45.

6. Gomez DE, Alonso DF, Yoshiji H, Thorgeirsson UP. Tissue inhibitors of metalloproteinases: structure, regulation and biological functions. Eur J Cell Biol 1997;74:111-22.

7. Blavier L, Henriet P, Imren S, Declerck YA. Tissue inhibitors of matrix metalloproteinases in cancer. Ann N Y Acad Sci 1999;878:108-19.

8. Kugler A. Matrix metalloproteinases and their inhibitors. Anticancer Res 1999;19:1589-92.
9. Baker AH, Ahonen M, Kahari V-M. Potential applications of tissue inhibitor metalloproteinase (TIMP) overexpression for cancer gene therapy. Adv Exp Med Biol 2000;465:469-83.

10. Murray GI, Duncan ME, O’Neil P, McKay JA, Melvin WT, Fothergill JE. Matrix metalloproteinase-1 is associated with poor prognosis in esophageal cancer. J Pathol 1998;185:25661.

11. Sier CFM, Kubben FJGM, Ganesh S, Heerding MM, Griffioen G, Hanemaaijer R, et al. Tissue levels of matrix metalloproteinases MMP-2 and MMP-9 are related to the overall survival of patients with gastric carcinoma. Br J Cancer 1996; 74:413-7.

12. Murray GI, Duncan ME, O'Neil P, Melvin WT, Fothergill JE. Matrix metalloproteinase- 1 is associated with poor prognosis in colorectal cancer. Nat Med 1996;2:461-2.

13. Talvensaari-Mattila A, Paakko P, Hoyhtya M, Blanco-Sequeiros G, Turpeenniemi-Hujanen T. Matrix metalloproteinase-2 immunoreactive protein: a marker of aggressiveness in breast carcinoma. Cancer 1998;83:1153-62.

14. Bramhall SR, Neoptolemos JR, Stamp GW, Lemoine NR. Imbalance of expression of matrix metalloproteinases (MMPs) and tissue inhibitors of matrix metalloproteinases (TIMPs) in human pancreatic carcinoma. J Pathol 1997;182: 347-55.

15. Kitamura H, Oosawa Y, Kawano N, Kameda Y, Hayashi H, Nakatani Y, et al. Basement membrane patterns, gelatinase A and tissue inhibitor of metalloproteinase-2 expressions, and stromal fibrosis during the development of peripheral lung adenocarcinoma. Hum Pathol 1999;30:331-8.

16. Kugler A, Hemmerlein B, Thelen P, Kallerhoff M, Radzun H-J, Ringert R-H. Expression of metalloproteinase2 and 9 and their inhibitors in renal cell carcinoma. J Urol 1998;160: 1914-8.

17. Young TN, Rodriguez GC, Rinehart AR, Bast RC Jr, Pizzo SV, Stack MS. Characterization of gelatinases linked to extracellular matrix invasion in ovarian adenocarcinoma: purification of matrix metalloproteinase2. Gynecol Oncol 1996;62: 89-99.

18. Murashige M, Miyahara M, Shiraishi N, Saito T, Kohno K, Kobayashi M. Enhanced expression of tissue inhibitors of metalloproteinases in human colorectal tumors. Jpn J Clin Oncol 1996;26:303-9.

19. Ree AH, Florenes VA, Berg JP, Malandsmo GM, Nesland JM, Fodstad O. High levels of messenger RNAs for tissue inhibitors of metalloproteinase (TIMP-1 and TIMP-2) in primary breast carcinomas are associated with development of distant metastasis. Clin Cancer Res 1997;3:1623-8.

20. Fong KM, Kida Y, Zimmerman PV, Smith PJ. TIMP-1 an adverse prognosis in non-small cell cancer. Clin Cancer Res 1996;2:1369-72.

21. Lokeshwar BL. MMP inhibition in prostate cancer. Ann N Y Acad Sci 1999;878:271-89.

22. Rabbani SA, Harakidas P, Guo Y, Steinman D, Davidsen SK, Morgan DW. Synthetic inhibitor of matrix metalloproteases decreases tumor growth and metastases in a syngeneic model of rat prostate cancer in vivo. Int J Cancer 2000;87: 276-82.

23. Nagakawa O, Murakami K, Yamaura T, Fujiuchi Y, Murata J, Fuse H, et al. Expression of membrane-type 1 matrix metalloproteinase (MT1-MMP) on prostate cancer cell lines. Cancer Lett 2000;155:173-9.

24. Sanchez-Sweatman OH, Orr FW, Singh G. Human metastatic prostate PC3 cell lines degrade bone using matrix metalloproteinases. Invasion Metastasis 1998-1999;18:297-305.

25. Luo J, Lubaroff DM, Hendrix MJ. Suppression of prostate cancer invasive potential and matrix metalloproteinase activity by E-cadherin transfection. Cancer Res 1999;59: 3552-6. 
26. Upadhyay J, Shekarriz B, Nemeth JA, Dong Z, Cummings GD, Fridman R, et al. Membrane type 1-matrix metalloproteinase (MT1-MMP) and MMP-2 immunolocalization in human prostate: change in cellular localization associated with high-grade prostatic intraepithelial neoplasia. Clin Cancer Res 1999;5:4105-10.

27. Still K, Robson CN, Autzen P, Robinson MC, Hamdy FC. Localization and quantification of mRNA for matrix metalloproteinase-2 (MMP-2) and tissue inhibitor of matrix metalloproteinase-2 (TIMP-2) in human benign and malignant prostatic tissue. Prostate 2000;42:18-25.

28. Stearns M, Stearns ME. Evidence for increased activated metalloproteinase 2 (MMP-2a) expression associated with human prostate cancer progression. Oncol Res 1996;8:69-75.

29. Stearns ME, Stearns M. Immunohistochemical studies of activated matrix metalloproteinase-2 (MMP-2a) expression in human prostate cancer. Oncol Res 1996;8:63-7.

30. Hamdy FC, Fadlon EJ, Cottam D, Lawry J, Thurrell W, Silcocks $\mathrm{PB}$, et al. Matrix metalloproteinase 9 expression in primary human prostatic adenocarcinoma and benign prostatic hyperplasia. Br J Cancer 1994;69:177-82.

31. Pajouh MS, Nagle RB, Breathnach R, Finch JS, Brawer MK, Bowden GT. Expression of metalloproteinase genes in human prostate cancer. J Cancer Res Clin Oncol 1991;117:144-50.

32. Sang QA, Schwartz MA, Li H, Chung LW, Zhau HE. Targeting matrix metalloproteinases in human prostate cancer. Ann N Y Acad Sci 1999;878:538-40.

33. Hashimoto K, Kihira Y, Matuo Y, Usui T. Expression of matrix metalloproteinase-7 and tissue inhibitor of metalloproteinase- 1 in human prostate. J Urol 1998;160:1872-6.

34. Lein M, Nowak L, Jung K, Laube C, Ulbricht N, Schnorr D, et al. Metalloproteinases and tissue inhibitors of matrixmetalloproteinases in plasma of patients with prostate cancer and in prostate cancer tissue. Ann N Y Acad Sci 1999; 878:544-6.

35. Jung K, Laube C, Lein M, Turk I, Lichtinghagen R, Rudolph B, et al. Matrix metalloproteinase-2 in blood does not indicate the progression of prostate cancer. Int J Cancer 1998;78:392-3.

36. Gohji K, Fujimoto N, Hara I, Fujii A, Gotoh A, Okada H, et al. Serum matrix metalloproteinase-2 and its density in men with prostate cancer as a new predictor of disease extension. Int J Cancer 1998;79:96-101.

37. Jung K, Nowak L, Lein M, Priem F, Schnorr D, Loening SA. Matrix metalloproteinases 1 and 3 , tissue inhibitor of metalloproteinase- 1 and the complex of metalloproteinase$1 /$ tissue inhibitor in plasma of patients with prostate cancer. Int J Cancer 1997;74:220-3.

38. Gleason DF. Histologic grading of prostate cancer: a perspective. Hum Pathol 1992;23:273-9.

39. Ohori M, Wheeler TM, Scardino PT. The new American Joint Committee on Cancer and International Union against Cancer. TNM classification of prostate cancer. Cancer 1994;74:104-14.

40. Kallakury BVS, Yang F, Figge J, Smith KE, Kausik SJ, Tacy NJ, et al. Decreased levels of CD44 protein and mRNA in prostate cancer. Correlation of tumor grade and ploidy. Cancer 1996;78:1461-9.

41. Kallakury BVS, Sheehan CE, Ambros RA, Fisher HAG, Kaufman RP Jr, Muraca PJ, et al. Correlation of p34 ${ }^{\text {cdc2 }}$ cyclindependent kinase overexpression, CD44s downregulation, and HER-2/ neu oncogene amplification with recurrence and prostatic adenocarcinomas. J Clin Oncol 1998;16:1302-9.

42. Ross JS, Figge H, Bui HX, del Rosario AD, Jennings TA, Rifkin $\mathrm{MD}$, et al. Prediction of pathologic stage and postprostatectomy disease recurrence by DNA ploidy analysis of initial needle biopsy specimens of prostate cancer. Cancer 1994;74:2811-8.

43. Ross JS, Sheehan CE, Ambros RA, Nazeer T, Jennings TA, Kaufman RP, et al. Needle biopsy DNA ploidy status predicts grade shifting in prostate cancer. Am J Surg Pathol 1999;23:296-301.
44. Sutinen M, Kainulainen T, Hurskainen T, Vesterlund E, Alexander JP, Overall CM, et al. Expression of matrix metalloproteinases (MMP-1 and -2) and their inhibitors (TIMP-1, -2, and -3 ) in oral lichen planus, dysplasia, squamous cell carcinoma and lymph node metastasis. Br J Cancer 1998;77: $2239-45$.

45. Zucker S, Hymowitz M, Conner C, Zarribi HM, Hurewitz AN, Matrisian L, et al. Measurement of matrix metalloproteinases and tissue inhibitors of metalloproteinases in blood and tissues. Clinical and experimental applications. Ann N Y Acad Sci 1999;878:212-27.

46. Yamamoto H, Adachi Y, Itoh F, Iku S, Matsuno K, Kusano M, et al. Association of matrilysin expression with recurrence and poor prognosis in human esophageal squamous cell carcinoma. Cancer Res 1999;59:3313-6.

47. Boag AH, Young ID. Immunohistochemical analysis of type IV collagenase expression in prostatic hyperplasia and adenocarcinoma. Mod Pathol 1993;6:65-8.

48. Hamdy FC, Fadlon EJ, Cottam D, Lawry J, Thurrell W, Silcocks PB, et al. Matrix metalloproteinase 9 expression in primary human prostatic adenocarcinoma and benign prostatic hyperplasia. Br J Cancer 1994;69:177-82.

49. Albini A, Melchiori A, Santi L, Liotta LA, Brown PD, StetlerStevenson WG. Tumor cell invasion inhibited by TIMP-2. J Natl Cancer Inst 1991;83:775-9.

50. Watanabe M, Takahashi Y, Ohta T, Mai M, Sasaki T, Seiki M. Inhibition of metastasis in human gastric cancer cells transfected with tissue inhibitor metalloproteinasel gene in nude mice. Cancer 1996;77:1676-80.

51. Bramhall SR, Stamp GW, Dunn J, Lemoine NR, Neoptolemos JP. Expression of collagenous (MMP2), stromelysin (MMP3) and tissue inhibitor of the metalloproteinases (TIMP1) in pancreatic and ampullary disease. Br J Cancer 1996;73:972-8.

52. Alonso DF, Skilton G, DeLorenzo MS, Scursoni AM, Yoshiji $\mathrm{H}$, Gomez DE. Histopathologic findings in a highly invasive mouse mammary carcinoma transfected with human tissue inhibitor of metalloproteinases-1. Oncol Rep 1998;5:1083-7.

53. Nemeth JA, Rafe A, Steiner M, Goolsby CL. TIMP-2 growth stimulatory activity: a concentration and cell-type specific response in the presence of insulin. Exp Cell Res 1996;224: $110-5$.

54. Grignon DJ, Sakr W, Toth M, Ravery V, Angulo J, Shamsa F, et al. High levels of tissue inhibitors metalloproteinase-2 (TIMP-2) expression are associated with poor outcome in invasive bladder cancer. Cancer Res 1996;56:1654-9.

55. Shofuda K, Moriyama K, Nishihashi A, Higashi S, Mizushima $\mathrm{H}$, Yasumitsu $\mathrm{H}$, et al. Role of tissue inhibitor of metalloproteinase-2 (TIMP-2) in regulation of pro-gelatinase A activation catalyzed by membrane-type matrix metalloproteinase-1 (MT1-MMP) in human cancer cells. J Biochem 1998;124:462-70.

56. Butler GS, Butler MJ, Atkinson SJ, Will H, Tamura T, VanWestrum SS, et al. The TIMP2 membrane type 1 metalloproteinase "receptor" regulates the concentration and efficient activation of pro-gelatinase A-a kinetic study. J Biol Chem 1998;273:871-80.

57. Toth M, Bernardo MM, Gervasi DC, Soloway PG, Wang Z, Bigg HF, et al. Tissue inhibitor of metalloproteinase (TIMP)-2 acts synergistically with synthetic matrix metalloproteinase (MMP) inhibitors but not with TIMP-4 to enhance the (membrane type 1)-MMP-dependent activation of pro-MMP-2. J Biol Chem 2000;275:41415-23.

58. Corcoran ML, Stetler-Stevenson WG. Tissue inhibitor of metalloproteinase-2 stimulates fibroblast proliferation via c-AMP-dependent mechanism. J Biol Chem 1995;270:13458-9.

59. Yamashita K, Suzuki M, Iwata H, Koike T, Hamaguchi M, Shinagawa A, et al. Tyrosine phosphorylation is crucial for growth signaling by tissue inhibitors of metalloproteinases (TIMP-1 and TIMP-2). FEBS Lett 1996;396:103-7. 
60. Guedez L, Stetler-Stevenson WG, Wolff L, Wang J, Fukushima $\mathrm{P}$, Mansoor A, et al. In vitro suppression of programmed cell death of $B$ cells by tissue inhibitor metalloproteinases-1. J Clin Invest 1998;102:2002-10.

61. Hayakawa T, Yamashita K, Ohuchi E, Shinagawa A. Cell growth promoting activity of tissue inhibitor metalloproteinases-2 (TIMP-2). J Cell Sci 1994;107:2373-9.
62. DeClerck YA, Yean TD, Chan D, Shimada H, Langley KE. Inhibition of tumor invasion of smooth muscle cell layers by recombinant human metalloproteinase inhibitor. Cancer Res 1991;51:2151-7.

63. Brown PD, Giavazzi R. Matrix metalloproteinase inhibition: a review of anti-tumour activity. Ann Oncol 1995;6: $967-74$.

\section{Book Review}

\section{Miettinen MM: Diagnostic Soft Tissue Pathol- ogy, 1st Edition, 800 pp, London, Churchill Livingstone, 2002 (\$199.00).}

With his book on soft tissue pathology, Dr. Markku Miettinen continues the tradition of the Chairs of the Department of Soft Tissue Pathology in publishing superb textbooks in this area of diagnostic pathology. This time it is a 800 -page, superbly illustrated (all microphotographs are in full color) review of traditional microscopic and up-to-date immunohistochemical and molecular genetic characteristics of lesions of the organ system commonly referred to as "soft tissues." Reading this outstanding book, one may wonder what constitutes soft tissues. The book goes into a great detail describing gastrointestinal stromal tumors, melanomas, and distribution of cytokeratins' expression; all this could be considered a bit of an unorthodox approach in writing of "soft tissues" textbook. However, these chapters and paragraphs are excellently incorporated into a textbook that provides the most recent views on the diagnosis and pathogenesis of entities found under the umbrella of soft tissues.

There are 21 chapters. A separate chapter on immunohistochemistry of soft tissue tumors is a marvel and a reflection of the author's extensive personal involvement in research and diagnostic applications of this technique. This is followed by a comprehensive chapter on the genetics of soft tissue tumors by Dr. Jerzy Lasota, again reflecting the great personal research experience of the author. Each following chapter deals with a traditional histogenetic group of tumors and consistently lists the most important clinical features, followed by the review of the most relevant histologic features, immunophenotype, and genetic alterations. The references are as recent as 2002, which is highly impressive.

This new book, although approximately onethird the size of the now classic Enzinger and Weiss's Soft Tissue Tumors, manages to cover the same territory without compromising the quality. Future research on molecular mechanisms will undoubtedly shed more light on understanding of the diseases of soft tissues, which will hopefully lead to new editions of this thoroughly modern book.

\section{Zoran Gatalica \\ Creighton University Medical Center \\ Omaha, Nebraska}

